\title{
Microbiological Evaluation of some Oral Antacid Suspensions Sold in Delta State, Nigeria
}

\section{${ }^{* 1}$ ANIE, CO: ${ }^{2} \mathrm{OKAFO}, \mathrm{SE}$}

\author{
${ }^{*}$ Department of Pharmaceutical Microbiology and Biotechnology; ${ }^{2}$ Department of Pharmaceutics and Industrial Pharmacy, Delta State \\ University, Abraka, Nigeria
}

*Corresponding Author Email: Oliseloke@yahoo.com, coanie@delsu.edu.ng; Tel: 08066390868

Other Author Email: sinokaf@yahoo.com,okafose@delsu.edu.ng

\begin{abstract}
Pharmaceutical products (non-sterile) are faced with the challenges of not exceeding the minimum limit of microbial presence tolerated for the respective formulations. Antacid suspensions which are multi-dose drug products that are utilized in the neutralization of gastric acid. This drug with neutral $\mathrm{pH}$ makes them to be liable to microbial contamination. This study was conducted to evaluate antacid suspensions marketed in Delta State, Nigeria based on their microbial quality. Six different brands of antacid suspensions were collected from different Pharmacies in Delta state and were analysed microbiologically to isolate and quantify the implicated bacteria and fungi using conventional cultural and biochemical techniques. The microbiological evaluation of these samples was determined using the agar-well diffusion method. Five out of the six brands evaluated were found to be populated with a huge number of bacteria $\left(2.5 \times 10^{2}\right.$ to $\left.>2.2 \times 10^{2} \mathrm{CFU} / \mathrm{ml}\right)$ and fungi $\left(2 \times 10^{2}\right.$ to $\left.8 \times 10^{2} \mathrm{CFU} / \mathrm{ml}\right)$. Staphylococcus aureus was absent in any of the antacids brands studied. However, there were presence of objectionable microorganisms, Escherichia coli and Candida albicans in three of the six brands. The results of this study reveal the microbial contamination level of some of the antacid (suspensions) marketed in Delta State which may be due to poor adherence to current good manufacturing practice by the manufacturers
\end{abstract}

\section{DOI: https://dx.doi.org/10.4314/jasem.v25i2.23}

Copyright: Copyright $\odot 2021$ Annie and Okafo. This is an open access article distributed under the Creative Commons Attribution License (CCL), which permits unrestricted use, distribution, and reproduction in any medium, provided the original work is properly cited.

Dates: Received: 12 December 2020; Revised: 26 January 2021; Accepted: 12 February 2021

Keywords: Antacid suspensions, Microorganisms, Microbiological quality, Brands.

Suspension as a dosage form is formed by dispersing solid particles in an aqueous or oily liquid in which the particles are poorly soluble or completely insoluble (Billany, 1999). Some drugs such as kaolin, magnesium carbonate and magnesium silicate are required to appear in the gastrointestinal tract in a finely divided form. When these drugs are formulated as suspensions, the desired high surface area is produced (Okafo and Chukwu, 2017). Antacids in suspension forms are utilized to neutralize hydrochloric acid in gastric secretions (Khan et al, 2014). The neutral $\mathrm{pH}$ of antacid suspensions makes them to be liable to microbial contamination and growth. Also, $\mathrm{pH}$ may influence the effectiveness of the preservative by producing changes in its ionization state which may distort the balance between the dissociated and un-dissociated forms. This could stop the activity of preservative from reaching a satisfactory protective concentration due to different inherent antimicrobial strength of the two forms (Aulton and Taylor, 2013). Some pharmaceutical products especially the oral drugs such as suspensions are usually not sterilized and are abound to have presence of various types of microbes as a result of non-ideal manufacturing condition (Stan, 2015). This may result in the deterioration of the pharmaceutical product. The extent of the microbial spoilage will depend on the chemical structure of the ingredient, type and quantity of contaminating microbes, concentration of preservative if present, $\mathrm{pH}$ and presence of sweeteners (Emejuru et al, 2014; Biraima et al, 2016). Consumption of contaminated pharmaceutical products has resulted in untoward health condition to the users and cases of drug-borne infections of man exists globally. The level of contamination by microorganisms depends on various factors that include availability of nutrients, microbial presence and oxygen. The effect of the drug-borne infection is determined by factors such as type and extent of contamination by microbes, route of administration and the immune system condition of the patient (Adeshina et al., 2009). The quality of drugs especially non sterile pharmaceuticals such as suspensions is of great concern and should be monitored from the acquisition of raw materials through the production process to testing of the final product. The final product must meet high microbiological standard, though not sterile, but the microbial content must not be above a minimum limit Biraima et al., (2016). Evaluation of microbiological quality of medicinal products is one of the major control measures in assessment of pharmaceutical products (Ratajczak et al., 2015). Factors that are considered in microbiological evaluation of 
pharmaceutical products include; the source and incidence of microbes in the product, the effect of such contamination on the stability of the product and patients' health, the levels and types of microbes that may be tolerated (Parker, 1999). The evaluation of such microbial quality is based on qualitative and quantitative tests that are employed to determine the microbial content as well as detection of specified objectionable ones (Biraima et al, 2016). The objective of this study is to evaluate the microbiological status of the six different brands of antacids (suspension) sold in various towns of Delta State, as this will inform the prescribers in this environment the conditions of these antacids sold in this area.

\section{MATERIALS AND METHODS}

Sampling and sample processing: Six samples of antacid suspensions (coded AT1-AT6) with valid manufacturing and expiry dates were collected between November and December 2019. These oral suspensions were collected from different community pharmacies in Obiaruku, Asaba and Warri in Delta State, Nigeria and were taken to the laboratory to establish microbiological quality these antacids. The total bacterial and fungal loads as well as presence of specific pathogens were determined following the standard methods Ratajczak et al., (2015)

Enumeration of total viable bacterial and fungal count: For enumerating the total viable bacterial and fungal load, on Nutrient agar (NA) and Sabouraud Dextrose agar (SDA) was spread $0.1 \mathrm{ml}$ of individual antacid suspension (Dafale et al, 2014). Nutrient and SDA plates were incubated for 24 hours at $37^{\circ} \mathrm{C}$ and at $25^{\circ} \mathrm{C}$ for 48 to 72 hours respectively.

Enumeration of specific pathogens: From each sample, $0.1 \mathrm{ml}$ of suspension was spread onto MacConkey agar and mannitol salt agar (MSA), for the isolation and enumeration of Escherichia coli and Staphylococcus spp. respectively. The plates were then incubated for 24 hours at $37^{\circ} \mathrm{C}$. The isolated strains were further identified by following confirmative biochemical tests (Dafale et al, 2014; Emejuru et al, 2013).

\section{RESULTS AND DISCUSSION}

Six (6) brands of antacids (suspension) from different pharmaceutical companies in Nigeria were evaluated physically and microbiologically. The results are shown on Tables 1 and 2.

Table 1: Physical assessment and microbial count for the different brands of oral antacid suspensions

\begin{tabular}{llllll}
\hline $\begin{array}{l}\text { Sample } \\
\text { code }\end{array}$ & Active ingredients & $\begin{array}{l}\text { Production } \\
\text { date }\end{array}$ & $\begin{array}{l}\text { Expiration } \\
\text { date }\end{array}$ & $\begin{array}{l}\text { Total Viable } \\
\text { Bacterial Count }\end{array}$ & $\begin{array}{l}\text { Total Fungal } \\
\text { Count }\end{array}$ \\
\hline AT1 & Magnesium trisilicate & May 2019 & June 2022 & $5.5 \times 10^{2}$ & $4.5 \times 10^{2}$ \\
AT2 & Magnesium trisilicate & July 2018 & June 2020 & $2.5 \times 10^{2}$ & $4.0 \times 10^{2}$ \\
AT3 & Magnesium trisilicate & August 2018 & Sept. 2021 & NG & NG \\
AT4 & Magnesium trisilicate & April 2019 & Feb. 2021 & $3 \times 10^{2}$ & $4.0 \times 10^{2}$ \\
AT5 & Magnesium trisilicate & Aug. 2019 & July 2022 & $1.2 \times 10^{3}$ & $2.0 \times 10^{2}$ \\
AT6 & Magnesium trisilicate & May 2019 & May 2021 & $2.0 \times 10^{3}$ & $2.5 \times 10^{2}$ \\
\hline
\end{tabular}

Table 2: Specific pathogens isolated from the different brands of the oral antacid suspensions

\begin{tabular}{|c|c|c|c|c|c|c|}
\hline & AT1 & AT2 & AT3 & AT4 & AT5 & AT6 \\
\hline $\begin{array}{l}\text { Staphylococcus } \\
\text { Aureus }\end{array}$ & $\mathrm{NG}$ & $\mathrm{NG}$ & $\mathrm{NG}$ & NG & $\mathrm{NG}$ & \\
\hline $\begin{array}{l}\text { Staphylococccus } \\
\text { Epidermidis }\end{array}$ & NG & NG & NG & $3 \times 10^{2}$ & $1.2 \times 10^{3}$ & $2.0 \times 10^{3}$ \\
\hline Micrococcus Spp. & $5.5 \times 10^{2}$ & NG & NG & NG & NG & NG \\
\hline Escherichia coli & TNTC & NG & NG & NG & $2.15 \times 10^{3}$ & NG \\
\hline Yersinia spp. & $\mathrm{NG}$ & TNTC & NG & NG & & \\
\hline Streptococcus spp. & NG & $2.5 \times 10^{2}$ & NG & NG & NG & $11 \times 10^{2}$ \\
\hline $\begin{array}{l}\text { Penicillium } \\
\text { notattum }\end{array}$ & NG & NG & NG & NG & $2 \times 10^{2}$ & $2.5 \times 10^{2}$ \\
\hline Aspergillus spp. & NG & NG & NG & $4 \times 10^{2}$ & NG & NG \\
\hline Candida spp. & $4.5 \times 10^{2}$ & $8 \times 10^{2}$ & NG & NG & NG & NG \\
\hline
\end{tabular}

Antacid (suspensions) usually are extremely susceptible to contamination by microorganisms mainly due to their neutral $\mathrm{pH}$. The study was carried out to ascertain whether some antacid suspensions sold in Delta State, Nigeria complied with the compendia microbiological standards particularly the USP specifications. It was observed that five out of six brands of the antacid suspensions (AT1, AT2, AT4, AT5 and AT6) tested exceeded the USP limit for total microbial content $\left(10^{2} \mathrm{CFU} / \mathrm{ml}\right)$. It was observed that none of the six (6) brands contained $S$. aureus, an objectionable microorganism. However, either one or two objectionable microorganisms (E. coli and
Candida albicans) were found in brands AT1, AT2 and AT5. Studies before now on microbiological quality of antacid suspensions carried out in Bangladesh Moniruzzaman et al., (2012) showed that some of the antacids sample were contaminated with $S$. aureus and $P$. aeruginosa. In a study carried out in Nigeria by Udeze et al (2012), Staphylococcus aureus was detected in the three samples evaluated. It looks from these results that amongst the offensive microorganisms, Staphylococcus aureus is the commonest which indicate that either inadequate personal hygiene as the Staphylococcus aureus is considered as part of the normal flora of human skin or 
production environment could also participate as a source of contamination with Staphylococcus aureus. In contrast to the study from Bangladesh and previous study from Nigeria, this study showed no presence of S. auerus which may suggest good personal hygiene of the workers. The presence of Candida albicans in two samples out of the six (6) antacid brands is indication of poor personal hygiene. The detection of E. coli in two of the brands indicates the presence of faecal contamination that may be as a result of poor water or raw materials sources. Brands AT1, AT2 and AT5 contained objectionable microorganisms and even TNTC quantity of some other organisms. This revealed low level of compliance to current good manufacturing practice (cGMP). Contaminations of finished pharmaceutical products are usually caused by poor hygiene by factory workers, poor environmental hygiene, contamination of raw materials and or machineries Khanom et al., (2013). Regulatory authorities should caution them to avoid endangering the health of end-users (patients). Brand AT3 did not show growth of any of the microbes used in the evaluation. This may be due to strict adherence to cGMP or due use of good preservatives. It has been said that the use of adequate preservative, hygienic manufacturing processes/environment and sterilization could be employed to inhibit or eliminate microbial growth in pharmaceutical preparations (Udeze et al, 2012).

Conclusion: This study results and other similar studies conducted in other areas of the globe on the microbiological quality of oral antacid suspensions, it looks like the producers of these antacids do face problem with the microbiological quality of these pharmaceutical products, this may as a result of the failure to implement efficiently all principles of GMP or failure to achieve effective preservation system. Regulatory bodies should also live up to expectation by monitoring strictly the activities of the manufacturers to avoid jeopardizing the health status of their citizens.

\section{REFERENCES}

Adeshina, GO; Ajayi, S; Onaolapo JA (2009). Microbiological quality of some commercially available paediatric anti-malarial and cough preparations in Ilorin, Nigeria. Nig. J. Pharm. Sci. 8(1): 109-117.

Aulton, ME; Taylor, KM (2013) Aulton's Pharmaceutics: the design and manufacture of medicines. Elsevier Health Sciences, 2013.

Billany, MR (1999). Suspensions. In: Aulton ME (ed) Pharmaceutics: The science of Dosage Forms Design, Churchill Livingstone, Edinburgh, pp269281.
Biraima, RE; Mohamed, SE; Hajo, MA; Elnazeer, AM; Hussain, MA (2016). Microbiological quality assessment of antacid suspensions available in Sudan. The Pharma Innov. J. 5(9): 17-19.

Dafale, NA; Semwal, UP; Agarwal, PK; Sharma, P; Singh, GN (2014). Evaluation of preservative effectiveness in antacid, cough syrup and ophthalmic solution by microbial challenge test. Int. J. Pharmacognosy 1(3): 193-199.

Khan, JA; Khan, IU; Iqbal, Z; Nasir, F; Muhammad, S; Hannan, PA et al (2015). Microbial spoilage, instability risk of antacid suspension in the presence of commonly used preservative system. Pak. J. Pharm. Sci. 28(5):1637-46.

Moniruzzaman, M; Ashrafi, FF; Mia, Z (2012). Qualitative and quantitative microbiological studies of antacid and paracetamol suspensions from different drugstores of Dhaka. Dhaka Univ. J. Biol. Sci. 21(1): 105-107

Okafo, SE; Chukwu, A (2017). Preliminary studies on the suspending properties of sida acuta gum in paracetamol suspension. World J. Pharm. and Pharm. Sci. 6(6): 302-313.

Parker, MS (1999). Microbiological contamination and preservation of pharmaceutical preparations. In: Aulton ME (ed) Pharmaceutics: The science of Dosage Form Design, Churchill Livingstone, Edinburgh pp479-490.

Ratajczak, M; Kubicka, MM; Kaminska, D; Sawicka, P; Dlugaszewska, J (2015). Microbiological quality of non-sterile pharmaceutical products. Saudi Pharm. J. 23: 303-307.

Stan, CD; Stefanachie, A; Tataringa, G; Dragan M; Tuchilus, CG (2015). Microbiological evaluation and preservative efficiency of new mandelic acid derivatives in ointments. Farmacia.63(4): 577580 .

Udeze, AO; Jayeoba, T; Innocent-Adiele, $\mathrm{HC}$; Okerentugba, PO; Nwanze, JC; Onoh, CC et al (2012). Bacteriological Assessment of Some Selected Antacid Suspension Products in Nigeria. N. Y. Sci. J. 5(5): 28-32.

United States Pharmacopoeia (2011). United States Pharmacopoieal Convention, Rockville, MD pp 48-50. 